\title{
The Training of the Typical Purwakarta Batik Design Creation in Improving Culture Existence
}

\author{
Wida Awaliya Nurkhaliza Meranti*, Zakarias S. Soeteja \\ Art Education Program \\ Universitas Pendidikan Indonesia \\ Bandung, Indonesia \\ *widaawaliyanm2@gmail.com, zakarias@upi.edu
}

\begin{abstract}
Seeing the level of public appreciation for a creation and culture today, it requires an appropriate innovation. Through reintroduction of local culture, we can gradually fostering society to foster a sense of belonging to one of their cultural heritage. In fostering the existence of culture and arts in a region, we need some efforts to preservation and development, one of them is the Batik's culture which has not developed much in the Purwakarta Regency. Therefore, seeing the local potential of Purwakarta Regency today it takes a creative training that has never been done before to generate innovative ideas that can be adapted to technological advances, so people can easily appreciate and take part in preserving their culture. The training method for the creation of Purwakarta's characteristics Batik design uses the exploration method which raises several elements of regional characteristics as a form of response to technological developments that increasingly require creativity in thinking and working. The expected results from this work are: 1) Fostering a sense of belonging the society for Batik as the Indonesian culture with the typical design of Purwakarta Regency 2) To be a motivation and reference for innovators and the young generation to create the next Batik's design product.
\end{abstract}

Keywords - training, batik, Puwakarta, innovation

\section{INTRODUCTION}

An area would want to preserve their culture. Of the many traditional arts and cultures that were inherited, until now there are still difficult to find because their existence has not documented. There's need some conservation and development efforts in fostering culture and arts in an area, one of them is the Batik culture which has not developed much in Purwakarta Regency.

One of the areas in West Java that has a variety of cultures and arts that's still maintained is Purwakarta Regency. There are; Tari Gerakan Nyere/Genye Dance, Pencak Silat Ibing, earthenware crafts/ceramics of Plered, and others. The culinary cultures also has a very strong existence, for example; Sate Maranggi, Simping, Peuyeum, Manisan Pala and Mangosteen which makes this region famous to foreign countries.

Seeing the potential of this area, the author feels that there is still one of Indonesia's traditional cultures that can be developed that has not yet been appear, which is Batik. Batik in
Purwakarta has been appear and developed when Kang Dedi Mulyadi served as Regent of Purwakarta Regency from 2008 to 2017. This batik pattern named Gapura Indung Rahayu is taken from the main shape of the gate which has become a characteristic of the boundaries of the area in Purwakarta, and the Batik is commonly used in clothes and in regional government events. Until now, the Batik pattern is still in good condition, but the fact there is still a lot of potential in this area that can be raised as a form of visualization into the typical of Batik design of Purwakarta.

Many forms of the potential of the Purwakarta area that can be used as Batik patterns, like one of them is Sate Maranggi. Certainly this form still requires creative innovations that can be adjusted so that people can easily appreciate this Batik as well. Departing from this topic, the writer has an interest in trying to create a typical Batik patterns design of Purwakarta as a response of technological developments and media exploration which increasingly demands creative thinking and work. So that an idea emerged to make this happen by holding a training aimed at several groups of young generation such as the handicraft community in Purwakarta Regency.

The training that will be carried out is related to the introduction of Batik through the creation of a typical Purwakarta Batik design. Seeing the Batik is a valuable part of the Indonesian nation's culture, it is necessary to introduce to people who are still unfamiliar with Batik culture. The purpose of making this training is so that people can easily recognize Batik with patterns that they usually encounter everyday, and make Purwakarta have a typical Batik design that can be formalized by the local government. various table text styles are provided. The formatter will need to create these components, incorporating the applicable criteria that follow.

\section{THEORETICAL}

According to Kamil, training has several elements in it, there are trainers, training participants, training processes and training materials. The four elements are related to each other and cannot be separated, because these four elements must be present in every training process [1]. 
The purpose of the training itself which was stated by Hamalik is to increase the competence of workers in the context of carrying out their duties and roles, as well as responsibilities, the increase in competence can be seen from the change in knowledge (attitude) of employees at work [2].

Basically the training and education have differences even though training itself is actually an educational process. Kamil distinguishes this difference into two points. First, education is a wider learning activity compared to training. Second, training has more to do with the development of certain skills, while education has more to do with levels of understanding in general [1].

Seeing this statement, the activity of creating the typical Batik design is included in the development of certain skills, where the skills in question include the skills to explore forms commonly encountered by people in their everyday. This exploration of patterns is also suggested by Suhersono, who explains that a patterns are design made from parts of shapes, various lines, or elements, which are sometimes strongly influenced by stylized forms of natural objects with distinctive features [3]. Batik patterns can be made with various lines, for example triangular, rectangular, curly or spiral lines, circular, winding (horizontal and vertical), twisting and intertwining lines, and lines that function as match shading [3].

Utoro explains that before the creation of Batik patterns, there are several steps that must be done, including:

\section{A. Make a Filling Form (Isen-Isen)}

The form of the filling can be in the form of a shape, a dot, or other variations. The variation in question is the form of filling that can be adjusted according to the ability of the creator [4].

\section{B. Merengga/Transform (Transform of Plants, Animals, Humans}

Merengga is a technique in making batik patterns by changing forms that exist in nature into forms of decoration [4].

\section{METHODS}

Soegiyono suggests that the research method is a scientific way to obtain data with specific purposes and uses. The method used in this research is a qualitative method designed with action research, which aims to develop new skills or new approaches and to solve problems by direct application in the world of work or other actual worlds [5] (see figure 1).

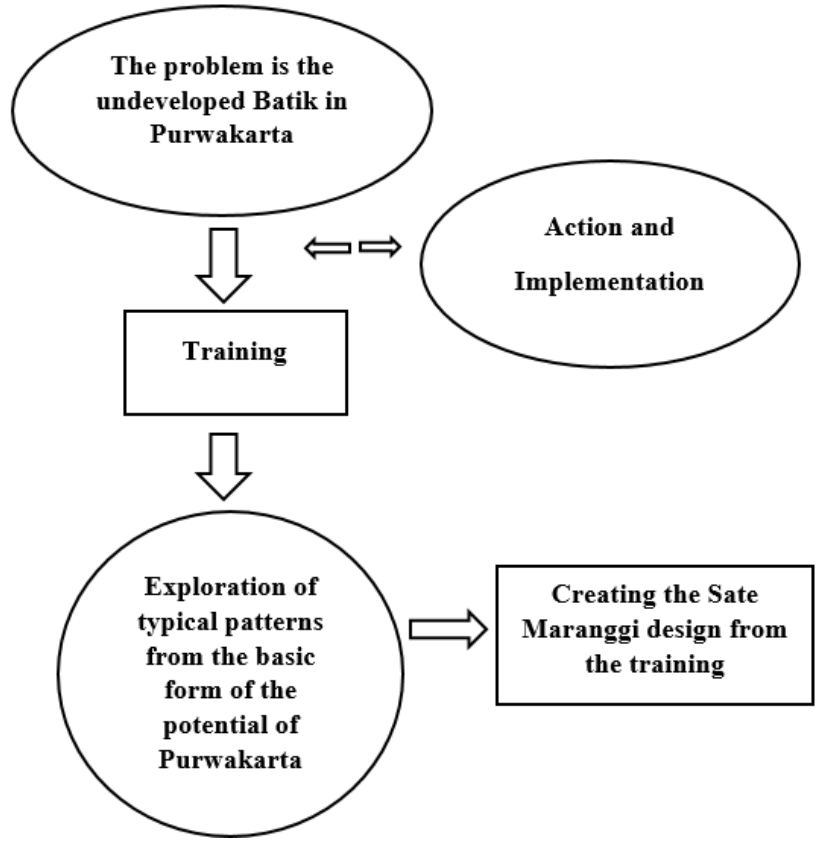

Fig. 1. Methods.

\section{RESULTS AND DISCUSSION}

This Purwakarta Batik design creation training was held to coincide with the 52nd anniversary of Purwakarta Regency. Through this important moment, several local figures and youth made several works and events as a form of belonging to their territory. This is makes the writer moved to take good opportunities to hold training in Batik creation that has never been held before. So as to be able to make the local youth office fully support the activities proposed. Ahmad Arif Imamulhaq, head of Youth and Sports in Purwakarta Regency, said that through this training, we are trying to educate the generation to want to preserve the nation's own culture and traditions. Like it or not, the tradition characterizes us. Of course, as long as the tradition does not conflict with religious values.

The most important thing in the creation of this work is the making of patterns design. The patterns that was developed came from the form of one of the regional potentials of Purwakarta Regency which was then developed into a new form that was interesting and memorable. Certainly before entering the stage of creating designs, the training participants are given a presentation of material or theoretical understanding so that the training practice runs according to the correct theory (see figure 2-8). 


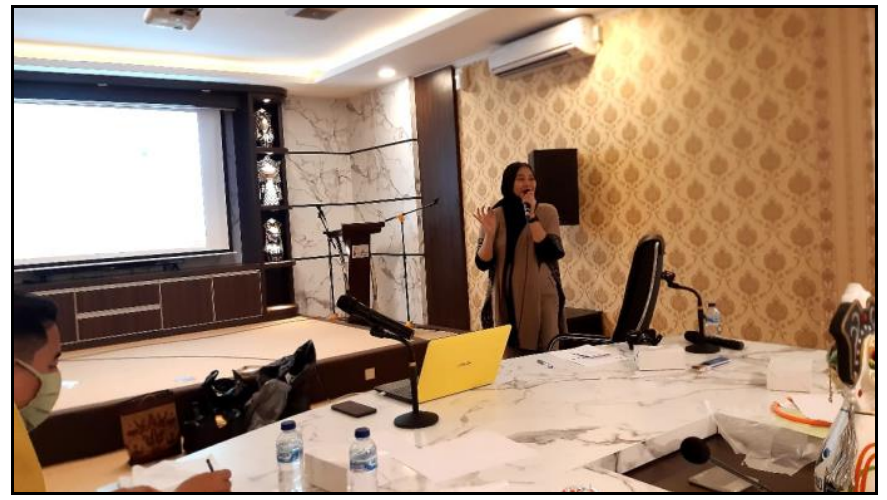

Fig. 2. Explanation some theory before practice.

The first stage is the manual stage, which is done by sketching the original shape of the patterns with pencil, then exploring it with decorations and giving isen-isen (stuffing).

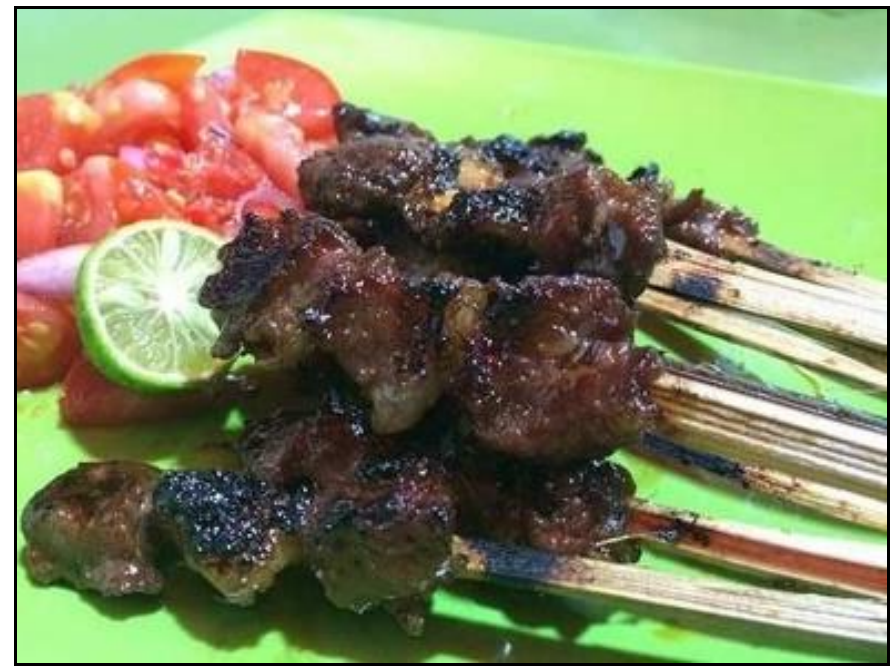

Fig. 3. Sate Maranggi photos.

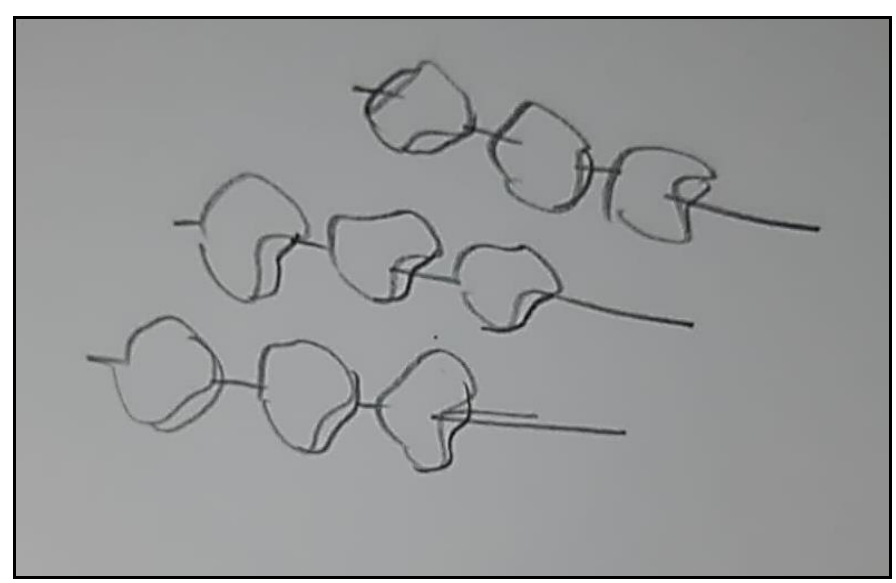

Fig. 4. Basic form of the objects.

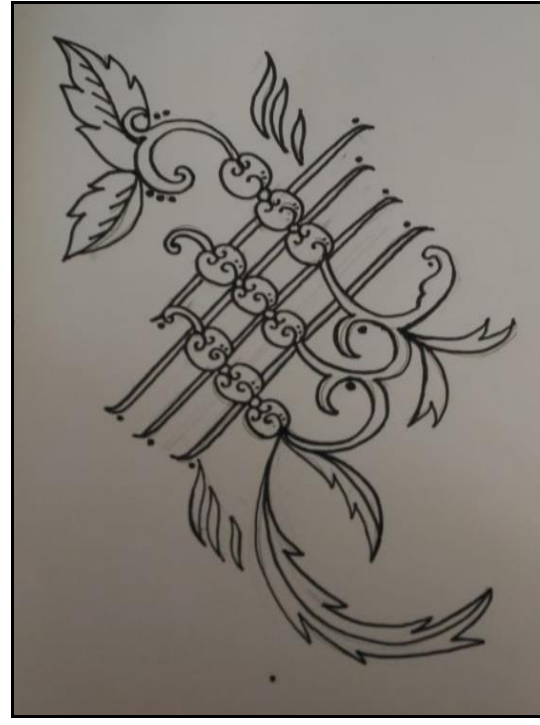

Fig. 5. Results of the transform (merengga).

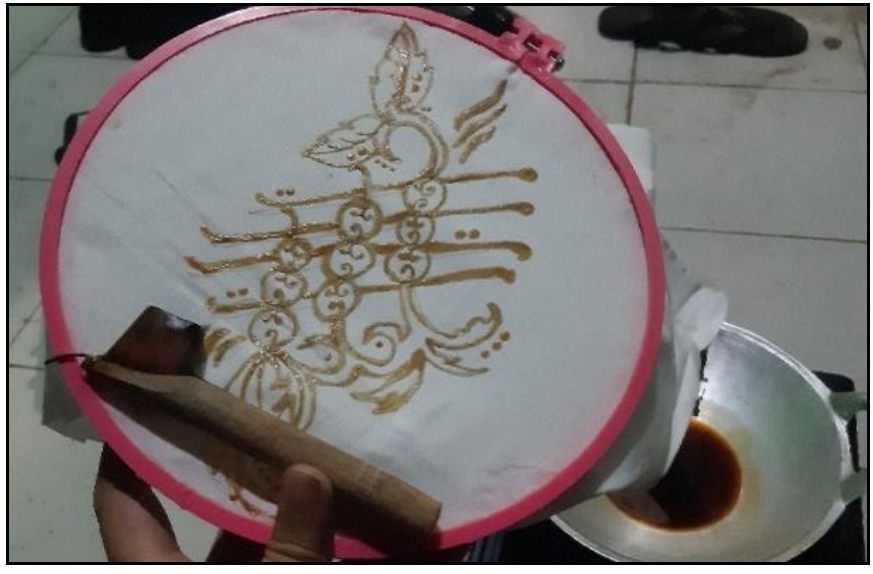

Fig. 6. Experiment on the fabric surface.

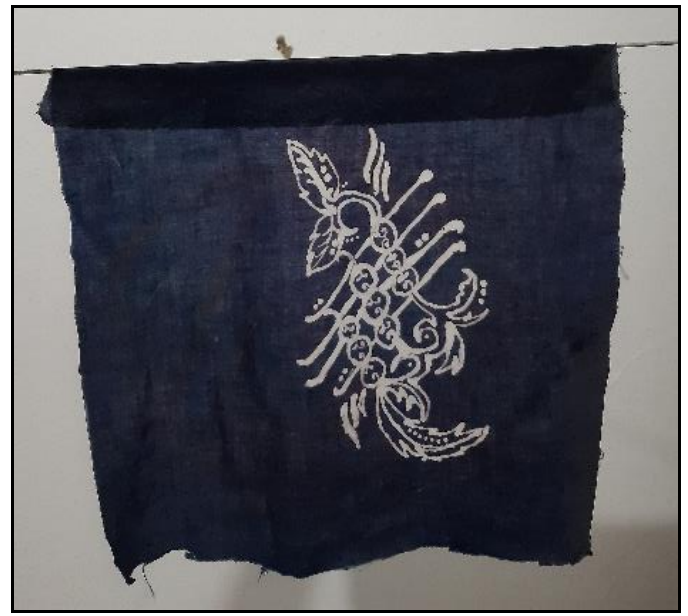

Fig. 7. The final result. 
The description of this patterns design is; like the Sate Maranggi should be, in this patterns the meat is arranged into 3 layers. The shape of the leaves explains the flourishing of Sate Maranggi in Purwakarta or the outside of region, the bright colors represent the nuances of simple but special like Sate Maranggi. The field of patterns in the form of rhombuses is related to education character in West Java, namely West Java Masagi, which includes surti, harti, evidence and devotion.

In line with Sunaryo which states that patterns in Nusantara based on decorative patterns are divided into five types, namely geometric motifs, human motifs, animal motifs, plant motifs, motifs of natural objects as well as motifs of technological and calligraphy objects [6].

From this statement it can be concluded that what is done to this form of design is an exploration of patterns. This was proven by the success of this training in creating new aesthetic design. Visually, the results of the exploration of this distinctive patterns produce interesting and fun works, this is because the participants of the training is the local people of Purwakarta Regency who are already familiar with the distinctive shape of Sate Maranggi, thereby increasing their motivation to work towards new things such as making this typical Batik pattern design.

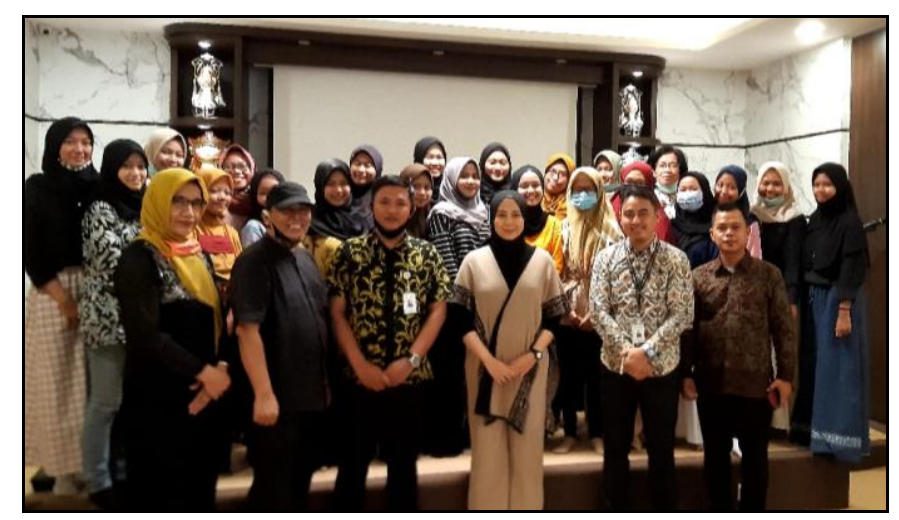

Fig. 8. Training participants and activity supporters.

\section{CONCLUSION}

Batik is a noble cultural heritage and has uniqueness that can describe the situation, characteristics and potential of an area, so can be a problem if an area is rich in culture but does not yet have stands out typical Batik design.

This Purwakarta Batik design creation training is a new research project in the Purwakarta Regency area. This research is expected to be an innovation for similar activities in the future, because the success of this research will have a positive impact on cultural development in the area, and can lead people to continue to think creatively and productively.

The typical Purwakarta Batik design was made in accordance with the training participant, they are the local citizen, handicraft community and another supporters that the author has designed and refers to the big theme of increasing cultural existence.

This training processess have several stages, such as providing basic theory to exploring the patterns which are expected to be of direct benefit to the community as a source of learning and motivation to work to explore creativity and potential.

\section{REFERENCES}

[1] M. Kamil, Model Pendidikan dan Pelatihan (Konsep dan Aplikasi). Bandung: Alfabeta, 2012.

[2] Hamalik, Manajemen Pelatihan Ketenagakerjaan Pendekatan Terpadu. Jakarta: Bumi Aksara, 2007.

[3] H. Suhersono, Desain Bordir Motif Fauna. Jakarta: PT. Gramedia Pustaka Utama, 2005.

[4] Utoro and B.A., Pola-Pola Batik dan Pewarnaan untuk SMK. Jakarta: Departemen Pendidikan dan Kebudayan, 1979.

[5] Soegiyono, Metode Penelitian Pendidikan, Bandung: IKAPI. 2008.

[6] A. Sunaryo, Ornamen Nusantara: Kajian Khusus tentang Ornamen Indonesia. Semarang: Dahara Prize, 2009. 